tion should gain popularity-among both patients and physicians.

Assistant Professor of Psychiatry

RAHUL MANCHANDA

University of Western Ontario

St Thomas Psychiatric Hospital,

St Thomas, Ontario,

Canada N5P 3V9

Professor of Psychiatry,

Charing Cross and Westminster Medical Schools,

London W6 8RF

1 Davis JM, Garver DL. Neuroleptics: clinical use in psychiatry. In: Iverson LL, Iverson SD, Snyder $\mathrm{SH}$, eds. Handbook of psychopharmacology vol 10: neuroleptics and schizophrenia. Snyder SH, eds. Handbook of
New York: Plenum Press, 1978 .

2 Davis JM. Overview: maintenance therapy in psychiatry: I. Schizophrenia. Am f Psychiatry 1975;132:1237-45.

3 Hogarty GE. Depot neuroleptics: the relevance of psychosocial factors-A United States perspective. I Clin Psychiatry 1984;45:36-42.

4 Johnson DAW. Antipsychotic medication: Clinical guidelines for maintenance therapy. 7 Clin Psychiatry 1985;46:6-15

5 Hirsch SR, Gaind R, Rhode PD, Stevens BC, Wing JK. Outpatient maintenance of chronic schizophrenic patients with long acting phenothiazines: double blind placebo trial. $\mathrm{Br} \mathrm{Med} \mathcal{F}$ 1973;i:633-7.

6 Hogarty GE, Ulrich RF. Temporal effects of drug and placebo in delaying relapse in schizophrenic outpatients. Arch Gen Psychiatry 1977;334:297-301.

Johnson DAW. Further observations on the duration of depot neuroleptic maintenance therapy in schizophrenia. Br f Psychiatry 1979;135:524-30.

8 Johnson DAW, Pasterski G, Ludlow JM, Street K, Taylor RDW. The discontinuance of maintenance neuroleptic therapy in chronic schizophrenic patients; drugs and social conmaintenance neuroleptic therapy in chronic schic
sequences. Acta Psychiat Scand 1983;67:339-52.

9 Baldessarini RJ, Davis JM. What is the best maintenance dose of neuroleptics in schizophrenia? Psychiatry Res 1980;3:115-22.

10 Kane JM, Rifkin A, Woerner $M$, et al. Low dose neuroleptic treatment of outpatient schizophrenics: 1. Preliminary results for relapse rates. Arch Gen Psychiatry 1983;40:893-6.

1 Marder SR, Van Putten T, Mintz J, et al. Costs and benefits of two doses of fluphenazine. Arch Gen Psychiatry 1984;41:1025-9.

12 Teicher MH, Baldessarini RJ. Selection of neuroleptic dosage. Arch Gen Psychiatry 1985;42: 636-7.

\section{In pursuit of the perfect rabies vaccine}

Just a century ago Louis Pasteur's first rabies treatment consisted of daily injections of a suspension of rabies infected spinal cord and eventually the inoculation of virulent rabies virus. This was crude and dangerous treatment, but the first recipients survived. The principle was thus established that rabies might be prevented by vaccination after exposure.

In 1911 Sir David Semple showed that rabies virus could be inactivated by treatment with phenol without altering its immunogenicity. ${ }^{1}$ Current Semple type vaccines are prepared from infected rabbit, sheep, or goat brains, inactivated with phenol, and given daily by injection for 14 to 21 or more days. They are still widely used, and for most of the world's poor are the only vaccine available. But they have unpleasant side effects: neuroparalytic accidents occur in about 1 in 2000 treatments, and $15 \%$ are fatal. ${ }^{2}$ Such vaccines cannot be recommended for immunisation before exposure.

To avoid neurological damage because of hypersensitivity to myelin other vaccines have been developed. One group is prepared from nervous tissue of newborn animals and contains less myelin. These vaccines are used mainly in Latin America, and the incidence of reactions is reduced but not eliminated. A second group is prepared from avian embryos, such as duck embryo, and, although neurological side effects are rare, sensitivity reactions to avian proteins are common. Both of these types are less potent than commercial cell culture vaccines but cheaper: they also may be given before exposure. The third new group is prepared from cultures of hamster kidney, bovine fetal kidney, dog kidney, chick embryo fibroblast, or human diploid cells. These vaccines are safe and potent and if the potency is $2 \cdot 5 \mathrm{IU}$ or more then a reduced schedule may be used for treatment with six doses given into the upper arm on days $0,3,7,14,30$, and $90 .^{3}$

The most extensively used cell culture vaccine is that prepared from human diploid cells. The first step was adapting rabies virus to grow in W1-38, a human diploid fibroblast cell line. ${ }^{4}$ Several years later a concentrated, purified vaccine of superior potency inactivated with $B$ propiolactone was produced commercially. Clinical trials confirmed its efficacy and safety, ${ }^{56}$ and in 1975 it was successfully used in Iran to treat 45 people bitten by confirmed rabid wolves or dogs. ${ }^{7}$ Since then many thousand doses of human diploid cell vaccine have been given world wide and only two cases of treatment failure reported (and neither case received optimum treatment). ${ }^{89}$ About 60000 doses of human diploid cell vaccine have been issued in Britain during the past 10 years. Over 4000 patients have been treated after possible exposure to rabies, and more than 6000 people at occupational risk have received vaccine before exposure. Side effects are generally minor, but type III hypersensitivity reactions have been reported in $1-7 \%{ }^{10}{ }^{11}$ and Guillain-Barré syndrome, with complete recovery, in two children. ${ }^{12} 13$

The high cost of human diploid cell vaccine limits its availability, and giving smaller volumes by multisite intradermal innoculation has been tried. For treatment after exposure $0.1 \mathrm{ml}$ human diploid cell vaccine has been given at eight sites on day 0 , four sites on day 7 , and single sites on days 28 and $91,{ }^{14}$ and with this regimen neutralising antibody was detected early.

Several cheaper cell substrates with higher virus yields may provide new vaccines. ${ }^{15-17}$ One of these, a purified vero cell rabies vaccine, has been tested in veterinary students in Thailand. ${ }^{18}$ The neutralising antibody responses to simulated postexposure regimens of purified vero cell vaccine and of human diploid cell vaccine were the same, and treatment trials are planned. Large scale production may be possible by growing vero cells on microcarriers in tanks. ${ }^{19}$

Cheaper vaccines may be produced in the future by genetic engineering. The gene encoding rabies glycoprotein (the essential component of rabies vaccines) has been cloned and expression obtained in Escherichia coli, yeast, and mammalian cells. ${ }^{20}$ These developments could lead to subunit vaccines-provided the synthesised glycoprotein is sufficiently immunogenic and gives protection both before and after exposure. The glycoprotein gene has also been inserted into the genome of vaccinia virus, and mice vaccinated with the live recombinant vaccinia rabies virus were protected against experimental rabies infection. ${ }^{20}$ Now that smallpox has been eradicated, however, live vaccinia virus, even if genetically modified, is unlikely to be acceptable for general use in man, and a safer vector is needed.

I must end on a note of caution: all vaccines are made using standard strains of rabies virus, and their efficacy against rabies related viruses found mainly in Africa is questionable. Two of these, Duvenhage and Mokola, have produced fatal encephalitis in man, and recently Duvenhage like viruses have been identified in a few European bats and have killed a Finnish zoologist. ${ }^{21}$ Polyvalent rabies vaccines may therefore be needed in the future.

Consultant Virologist,

SYLVIA D GARDNER

Virus Reference Laboratory,

Central Public Health Laboratory,

London NW9 5HT

1 Semple D. The preparation of $a$ safe and efficient antirabic vaccine. Calcutta: Superintendent Government Printing, India, 1911. (Scientific memoirs by Officers of the Medical and Sanitary Departments of the Government of India, No 44)

2 Hattwick MAW. Human rabies. Public Health Rev 1974;3:229-74. 
World Health Organisation Expert Committee on Rabies. Seventh report. Geneva: World Health Organisation, 1984. (Technical Report Series No 709 .

4 Wiktor TJ, Fernandes MV, Koprowski $H$. Cultivation of rabies virus in human diploid cell strain W1-38. F Immunol 1964;93:353-66.

Aoki FY, Tyrrell DAJ, Hill LE, Turner GS. Immunogenicity and acceptability of a human diploid cell culture rabies vaccine in volunteers. Lancet 1975;i:660-2.

Bahmanyar M. Results of antibody profiles in man vaccinated with various schedules. Symposium Series on Immunobiological Standardisation 1974;21:231-9.

7 Bahmanyar M, Fayaz A, Nour-Salehi S, Mohammadi M, Koprowski H. Successful protection of humans exposed to rabies infection. Post-exposure treatment with the new human diploid cell rabies vaccine and anti-rabies serum. FAMA 1976;236:2751-4.

8 Devriendt J, Staroukine $M$, Costy F, Vanderhaeghen J-J. Fatal encephalitis apparently due to rabies. Occurrence after treatment with human diploid cell vaccine but not rabies immune globulin. FAMA 1982;248:2304-6.

Wattanasri S, Boonthai P, Thongcharoen P. Human rabies after late administration of human diploid cell vaccine without hyperimmune serum. Lancet 1982;ii:870.

10 Gardner SD. Prevention of rabies in man in England and Wales. In: Pattison JR, ed. Rabies a growing threat. Wokingham: van Nostrand Reinhold, 1983:39-49.

11 Anonymous. Systemic allergic reactions following immunization with human diploid cell rabies vaccine. MMWR 1984;33:185-7.

12 Boe $\mathrm{E}$, Nyland $\mathrm{H}$. Guillain-Barré syndrome after vaccination with human diploid cell rabies vaccine Scand Infect Dis 1980;12:231-2.

vaccine. Scand $\mathcal{F}$ Infect Dis $1980 ; 12: 231-2$.
Bernard KW, Smith PW, Kader FJ, Moran

, Smith PW, Kader FJ, Moran MJ. Neuroparalytic illness and human diploid cell 982;248:3136-8

4 Warrell MJ, Suntharasamai P, Nicholson KG et al. Multisite intradermal and multisite subcutaneous rabies vaccination: improved economical regimens. Lancet 1984;i:874-6.

15 Atanasiu P, Perrin P, Segre L, Manganas O. Evaluation and comparative studies of inactivated rabies vaccines obtained in the heterologous diploid and polyploid cells (HAK, BHK and Vero). Developments in Biological Standardization 1982;50:173-82

16 Berlin BS, Mitchell JR, Burgoyne GH, Brown WE, Goswick C. Rhesus diploid rabies vaccine (adsorbed) a new rabies vaccine. Results of clinical studies simulating prophylactic therapy for rabies exposure. FAMA 1983;249:2663-5.

7 Barth $\mathrm{R}$, Gruschkau $\mathrm{H}$, Bijok $\mathrm{U}$, et al. A new inactivated tissue culture rabies vaccine for use in man. Evaluation of PCEC-vaccine by laboratory tests. F Biol Stand 1984;12:29-46.

18 Suntharasamai $\mathrm{P}$, Chanthavanich $\mathrm{P}$. Warrell $\mathrm{MJ}$, et al. Purified vero cell rabies vaccine and human cell strain vaccine: comparison of neutralising antibody responses to post-exposure regimens. fHyg 1986;96:483-9.

19 Roumiantzeff M, Ajian N, Branche R. et al. Rabies vaccine produced in cell culture: production control and clinical results. In: Kurstak E, ed. Applied virology. London: Academic Press, 1984:241-96.

20 Lecocq JP, Kieny MP, Lemoine Y, et al. New rabies vaccines: recombinant DNA approaches. In: Koprowski H, Plotkin SA, eds. World's debt to Pasteur. New York: Alan R Liss, 1985:259-71.

21 World Health Organisation Collaborating Centre for Rabies Surveillance and Research, Tuebingen, Federal Republic of Germany. Information on bat rabies in Europe. Rabies Bulletin Europe 1986;10:11-2(Ab 1/86)

\section{Why nursing education has to change}

Florence Nightingale said that "Reports are not selfexecutive," and nothing could be more true of the many reports on nursing education. The past 50 years have seen at least six-Athlone (1938), Horder (1943), Wood (1947), Platt (1964), Briggs (1972), and Judge (1985). All made remarkably similar recommendations, and none was implemented (apart from small changes at the margins). To expect too much from the latest report-Project 2000: A New Preparation for Practice-would thus be (in Oscar Wilde's words) a "triumph of optimism over experience."

But Project 2000 is different. Firstly, all sections of the nursing profession (a group not noted for its unity) appear to agree for the first time not only on the need for change but also on its key components. Secondly, the case for change this time supports the self interest of the service providers as well as the aspirations of nursing visionaries. Thirdly, the proposals come from the body that has the legal responsibility for establishing and improving the standards of training and practice of nurses; it thus has the power to implement its proposals.

Project 2000 has come from the United Kingdom Central Council for Nursing, Midwifery, and Health Visiting, the statutory body formed in 1979 by the amalgamation of all the bodies previously responsible for the education and regulation of the three parts of the nursing profession. It describes the changes needed in the training of nurses, midwives, and health visitors to enable them to meet the needs of the 1990s and beyond. The council also states its perceptions of the roles and responsibilities of nurses. Although Project 2000 is a consultation document addressed primarily to nurses, there is no doubt about the council's commitment to change or about its main direction.

The proposals are radical, and the aim is to produce a registered practitioner (the word practitioner is used as shorthand for the cumbersome specification of the three separate parts of the nursing profession) who is competent to assess nursing needs, provide nursing care, and monitor and evaluate the care given. She is to be a "knowledgeable doer" with analytical as well as technical skills, capable of autonomous practice, and fully accountable for her decisions. A new aim is that she should be able to practise at this basic level in both institutions and the community.

The core recommendation-for a two year common foundation course followed by one year's specialisation - is a reasonable compromise between the "genericists" and those who have advocated direct entry into the specialties. It will provide a sound basis for the later training needed by new specialist practitioners, who will be the future ward sisters, team leaders, teacher practitioners, and clinical managers. This is the beginnings, at last, of a clinical career structure. There is a clear commitment to preparing nurses who will nurse-in contrast to the position now, when patients are nursed (at least in hospitals) by unqualified auxiliaries and unskilled neophytes while the qualified nurses merely supervise.

The key change here-one advocated by every review of nursing education since the $40 \mathrm{~s}-$ is an end to the dependence of the hospital services on student labour. Separation of the funding of education from the service budget and removal of the students from the staff establishment will enable the student's clinical experience to be based on learning needs rather than the exigencies of the service. The education will become much broader, more community orientated, and based on a health orientated nursing model instead of the disease orientated medical model, which, quite properly, dominates medical practice. Those who once believed that hospitals could not survive without student labour now realise not only that students are no longer cheap (already only about $20 \%$ of their paid time is spent providing service) but also that an ever changing, unpredictable, and unskilled workforce is wasteful. Project 2000 may succeed where its predecessors failed simply because this time the costs of doing nothing are greater than the price of change.

JUNE CLARK

Special Projects and Community Nursing Officer,

Lewisham and North Southwark Health Authority, London SE1 9RT

\section{Blood transfusions and cancer: anomalies explained?}

Had we the ancients' respect for blood we should not think of a tranfusion as the mere replenishment of oxygen carrying capacity. We can assemble an impressive series of the unexpected consequences of transfusing blood. Older rheumatologists tell of remissions in rheumatoid arthritis begun by blood transfusion. ${ }^{1}$ Recently spontaneous abortion has been shown to be preventable in some cases by a transfusion of husband's blood. ${ }^{2}$ The effect of blood transfusion on renal allografts has been disputed ever since 1973, when Opelz and Teraski ${ }^{3}$ suggested, to much scepticism, 